\title{
THE ADMISSIBILITY OF Subregional Courts' DeCISIONS BEFORE THE AFRICAN COMMISSION OR AFrICAN COURT
}

Abdi Jibril Ali *

\begin{abstract}
Some courts of Regional Economic Communities deal with human rights and they base their decisions on the African Charter on Human and Peoples' Rights. Other subregional courts have directly or indirectly considered human rights matters. However, it is not clear whether the cases decided by subregional courts are admissible before the African Commission on Human and Peoples' Rights or the African Court on Human and Peoples' Rights. Focusing on the Economic Community of West African States Court of Justice, the East African Court of Justice, and the Southern African Development Community Tribunal, I argue that the African Commission or the African Court should not admit cases decided by subregional courts. First, accepting such cases would overburden the African Commission and the African Court. Second, the decisions of subregional courts are final according to the treaties establishing them. Third, states should not be tried twice by international institutions for the same violation. Fourth, decisions of subregional courts have res judicata effect. Fifth, subregional courts are envisaged under Article 56(7) of the African Charter. Finally, the African Court or the African Commission can interpret the text of the African Charter to preclude the admissibility of cases decided by subregional courts.
\end{abstract}

\section{Key words}

Admissibility, African Commission, African Court, subregional courts, res judicata

DOI http://dx.doi.org/10.4314/mlr.v6i2.3

\section{Acronyms and Abbreviations}

RECs

EAC

Regional Economic Communities

East African Community

\footnotetext{
* LLB (Haramaya University), LLM (University of Pretoria); Postgraduate Diploma (Åbo Akademi University); Lecturer and Post-Graduate Programme Coordinator, School of Law, Addis Ababa University; <abdeejibril@gmail.com>. The author is very grateful to Professor Frans Viljoen and Assistant Professor Brooke I GlassO'Shea for their constructive comments. He also thanks the anonymous reviewers for their comments. Any remaining errors are the author's sole responsibility.
} 
SADC Southern African Development Community

EACJ East African Court of Justice

ECOWAS Economic Community of West African States

ICCPR International Covenant on Civil and Political Rights

OP-CEDAW Optional Protocol to the Convention on the Elimination of Discrimination against Women

\section{Introduction}

African states have established Regional Economic Communities (RECs) to achieve increased trade and improved economic links. ${ }^{1}$ RECs serve as the building blocks for the economic integration of Africa. ${ }^{2}$ While pursuing these goals, they recognise the enhanced role of human rights, inter alia, as a means to their economic development. ${ }^{3}$ In the Algiers Declaration, African leaders identified a political environment in which human rights are observed as a precondition to economic growth. ${ }^{4}$ They also recognised that conflict, one of the obstacles to economic growth, may arise from the violation of human rights. ${ }^{5}$ For these reasons and others, RECs are involved in human rights matters.

Treaties establishing the RECs recognise the promotion and protection of human rights among their principles and different organs have been established to achieve these objectives. ${ }^{6}$ Some of these organs contribute to human rights

${ }^{1}$ Frans Viljoen (2007), International Human Rights Law in Africa (Oxford: Oxford University Press), p.495.

${ }^{2}$ Art 88(1), Treaty Establishing the African Economic Community, adopted in 1991 in Abuja, Nigeria and entered into force in 1994.

${ }^{3}$ See Magdalena Sepúlveda et. al. (2004), Human Rights Reference Handbook (San Jose: University for Peace), p.403; Oliver Christian Ruppel 'Regional economic communities and human rights in East and southern Africa' in Anton Bösl \& Joseph Diescho (eds) (2009),Human Rights in Africa: Legal Perspectives on their Protection and Promotion (Windhoek: Macmillan Education), p. 279. Respect for human rights immensely contributes to economic development. See also Nneoma Nwogu (2007), 'Regional integration as an instrument of human rights: Reconceptualizing ECOWAS, Journal of Human Rights 345.

${ }^{4}$ Declaration on the Political and Socio-economic Situation in Africa and the Fundamental Changes Taking Place in the World (the Algiers Declaration), OAU Doc AHG/Decl.1(XXVI), para 10 - 11.

${ }^{5}$ Rachel Murray (2004), Human Rights in Africa: from the OAU to the African Union (Cambridge: Cambridge university Press), p.126.

6 See Consolidated Text of the Treaty of the Southern African Development Community (as Amended), art 4(c); Treaty Establishing the East African Community, art 6(d); Treaty of ECOWAS, art 4(g); COMESA Treaty, art 6(e). These treaties were reproduced in Solomon Ebobrah \& Armand Tanoh (eds) (2010), Compendium of 
through setting standards. ${ }^{7}$ Other organs of RECs such as subregional courts can positively contribute to the protection of human rights. Subregional courts are organs of RECs vested with judicial powers. Some of them have decided human rights cases. Although it is advantageous to have as many institutions as possible to enhance the promotion and protection of human rights, overlapping judicial powers of organs raise concerns such as the possibility of divergent conclusions on the same issues, duplication of efforts, and inefficient allocation and use of scarce resources, particularly when different courts have jurisdiction over the same case. ${ }^{8}$

In Yogogombaye $v$ Senegal, the African Court on Human and Peoples' Rights (African Court) was confronted with issues that had already been raised before the ECOWAS Community Court of Justice. ${ }^{9}$ Such issues render the discussion on admissibility of cases decided by subregional courts before the African Court relevant. Although such a case has never been presented to the African Commission on Human and Peoples' Rights (African Commission), it is important to discuss admissibility before it because the African Commission is the main forum through which cases come to the African Court. So far, few countries have made declarations under Article 34(6) of the African Court Protocol and individuals or NGOs can bring cases to the African Court against these states only. Cases against other states should come to the African Court through the African Commission. ${ }^{10}$

African Sub-Regional Human Rights Documents (Pretoria: Pretoria University Law Press).

${ }^{7}$ The supreme organs of the RECs adopt instruments that address human rights issues.

${ }^{8}$ See Viljoen (2007), supra note 1, p. 501; Abdul Rahaman Lamin 'African subregional human rights courts: the ECOWAS Court of Justice, the SADC Tribunal and the EAC Court of Justice in comparative perspective' in John Akokpari \& Daniel Shea Zimbler (eds) (2008), Africa's Human Rights Architecture (Fanele: Auckland Park), p.239; Kithure Kindiki (2006) 'The African Human Rights System: Unnecessary Overlap or Useful Synergies?' East African Journal of Peace and Human Rights Vol. 12, p. 332.

${ }^{9}$ Yogogombaye v Senegal (2009) AHRLR 315 (ACtHPR 2009). The case was brought to the African Court to obtain suspension of proceedings instituted by Senegal in order to charge, try and sentence Mr Hissein Habré, former Head of State of Chad who had asylum in Senegal. The African Court declared the case inadmissible on the ground that the applicant lacks standing. See also Hissein Habré v Republic of Senegal, General Role No. ECW/CCJ/APP/07/08 Judgment No: ECW/CCJ/JUD/06/10, ruling delivered on 18 November 2010. The same case was brought before the ECOWAS Court of Justice on 6 October 2008 and was decided on 18 November 2010.

${ }^{10}$ See African Commission on Human and Peoples' Rights $v$ the Great Socialist Libyan People's Arab Jamahiriya, Application No. 004/2011, ruling 2 September 2011. The African Court rejected most cases on the ground that the respondent state did not make declaration under art 34(6) of the African Court Protocol. See, for example, 
Regulating the admissibility of cases decided by subregional courts would alleviate problems such as duplication of efforts or the possibility of divergent conclusions. The article addresses this issue in four sections. The first section provides the background on subregional courts and briefly discusses their establishment and human rights mandate. Section 2 provides an overview of Article 56(7) of the African Charter on pending and settled matters in relation to other international and regional human rights instruments. Section 3 discusses the reasons why cases decided by subregional courts should not be admitted before the African Commission or the African Court on Human and Peoples' Rights (the African Court).

\section{Human Rights Mandate of Subregional Courts}

Most treaties establishing Regional Economic Communities (RECs) that were adopted or revised after the adoption of the African Charter recognise the promotion and protection of human rights as one of their principles. ${ }^{11}$ These treaties have established judicial bodies that, to some extent, have been dealing with human rights matters. The ECOWAS Community Court of Justice is the pioneer in upholding human rights because it has clear human rights jurisdiction. The East African Court of Justice and the SADC Tribunal have also dealt with human rights matters.

\subsection{ECOWAS Community Court of Justice}

The Economic Community of West African States (ECOWAS) was established in 1975 with the objective of economic integration. ${ }^{12}$ In July 1993, the member states revised the Establishing Treaty. ${ }^{13}$ One reason for the revision seems to have been the developments in the field of human rights in ECOWAS and the

Daniel Amare and Mulugeta Amare v Republic of Mozambique and Mozambique Airlines, application No. 005/2011, Decision of 16 June 2011; National Convention of Teachers Trade Union v The Republic of Gabon, Application No 012/2011, decision 15 December 2011; Delta International Investments S.A., Mr and Mrs A.G.L. De Lange v The Republic of South Africa, Application No 002/2012, decision 30 March 2012; Emmanuel Joseph Uko and Others $v$ The Republic of South Africa, Application No 004/2012; Amir Adam Timan v The Republic of Sudan, Application No 005/2012, decision 30 March 2012; Baghdadi Ali Mahmoudi v. The Republic of Tunisia, Application No 007/2012, decision 26 June 2012.

11 Supra note 6.

${ }^{12}$ Solomon Ebobrah (2007), 'A Rights-Protection Goldmine or A Waiting Volcanic Eruption? Competence of, and Access to, the Human Rights Jurisdiction of the ECOWAS Community Court of Justice', African Human Rights Law Journal 309, Vol. 7, p. 309.

${ }^{13}$ Ibid, p. 310. 
continent. $^{14}$ The revised ECOWAS Treaty re-established the ECOWAS Community Court of Justice together with seven other organs of the Community. ${ }^{15}$

The Protocol on the ECOWAS Court did not confer human rights jurisdiction on the Court. ${ }^{16}$ The Court acquired jurisdiction on human rights in 2005 by a Supplementary Protocol amending the establishing Protocol of $1991 .^{17}$ The human rights jurisdiction of the ECOWAS Court is the power to hear cases for violations of 'the so-called Community rights endowed on ECOWAS citizens' and the power of the Court to receive cases on violations of the African Charter. ${ }^{18}$ The former is similar with the inter-state complaint mechanism of the African Charter as 'the ECOWAS Commission acquires access to bring human rights case against a member state where the state fails to perform its human rights obligations under the ECOWAS legal regime. ${ }^{19}$

The ECOWAS Court of Justice's jurisdiction on human rights is largely due to the recognition that human rights and access to justice in the sub-region are fundamental values of the ECOWAS Community enshrined in Articles 4(g), 56(2) and 63(2) of the 1993 Revised ECOWAS Treaty and Articles 9(4) and 10 (d) of the 2005 supplementary protocol. ${ }^{20}$ Individuals can also bring complaints that allege violation of the African Charter and other human rights instruments before the ECOWAS Court. ${ }^{21}$ The following examples illustrate this point.

14 The Preamble to the Treaty of ECOWAS, adopted by the Heads of State and Government of the Member States of ECOWAS in Cotonou on 24 July 1993. The preamble refers to African Charter on Human and Peoples' Rights and the 1991 Declaration on Political Principles of the Economic Community of West African States.

${ }^{15}$ Art 6(1)(e) \& art 15, the Treaty of ECOWAS. See A Banjo 'The ECOWAS Court and the politics of access to justice in West Africa' (2007) 32 Africa Development 73.

${ }^{16}$ Protocol A/P/1/7/91 on the Community Court of Justice adopted on 6 July 1991 in Lagos, Nigeria and entered into force on 5 November 1996.

${ }^{17}$ Supplementary Protocol A/SP1/01/05 to Protocol on the Community Court of Justice (1991) adopted in 2005 which provisionally came into force upon signature in 2005 , reproduced in Ebobrah \& Tanoh, supra note 6, p. 199.

${ }^{18}$ Enyinna S. Nwauche 'Regional economic communities and human rights in West Africa and the African Arabic countries' in Anton Bösl \& Joseph Diescho (eds) (2009) Human rights in Africa: Legal perspectives on their protection and promotion 332.

${ }^{19}$ Ebobrah, supra note 12, p. 314.

${ }^{20}$ Muhammed Tawfik Ladan (2009), Introduction to ECOWAS Community Law and Practice: Integration, Migration, Human Rights, Access to Justice, Peace and Security (Zaria: The Ahamdu Bello University Press), p. 269-280.

${ }^{21}$ See Nwauche, supra note 18, p. 332; Ebobrah, supra note 12, p. 314. 
In Manneh v The Gambia, the Court considered a case submitted against The Gambia by legal counsels of Chief Ebrimah Manneh, a Gambian journalist who was arrested without warrant by two officials of the National Intelligence Agency of The Gambia. ${ }^{22}$ The officials did not give any reason for his arrest. The plaintiff had been detained incommunicado. He had been detained for more than a year without any criminal charge. The counsels for the plaintiff submitted that the defendant violated Articles 4, 5, 6 and 7 of the African Charter. They requested the Court to order the defendant to release the plaintiff and pay him five million US dollars in damages. Although the defendant refused to make an appearance, the Court heard witnesses and found that Articles 2, 6 and 7(1) of the African Charter were violated. ${ }^{23}$ The Court also ordered the defendant to pay US $\$ 100,000$ to the plaintiff as damages. ${ }^{24}$

In Koraou v Niger, the Court considered a case of Hadijatou Mani Koraou, a Nigerien woman who was sold at the age of 12 to a 46 years-old man as "the fifth wife" called sadaka for the sum of 240,000 CFA Francs. ${ }^{25}$ The sale was conducted according to wahiya practice which was prevalent in Niger and consisted of "acquiring a young girl, generally under the conditions of servitude, for her to serve both as domestic servant and concubine." 26 "The sadaka generally carries out the domestic chores and caters for the "master" who can engage her in sexual relations at any time. ${ }^{27}$ The plaintiff had served her master for nine years and obtained a certificate of emancipation from him in $2005{ }^{28}$

However, the 'master' refused to let the plaintiff free even after she obtained certificate of emancipation. ${ }^{29}$ She escaped from her master and brought a case against him which led to a judgment that she had never been married to her master. ${ }^{30}$ While her civil case was being considered by appellate courts, the plaintiff was prosecuted for bigamy upon the complaint of the master. ${ }^{31}$ The plaintiff, her brother and her husband were sentenced to six months imprisonment and a fine, and they were incarcerated until they were released on appeal. $^{32}$

\footnotetext{
${ }^{22}$ Manneh v The Gambia (2008) AHRLR 171 (ECOWAS 2008), para 5.

${ }^{23}$ Ibid, para 41.

${ }^{24}$ Ibid, para 44

${ }^{25}$ Koraou v Niger (2008) AHRLR 182 (ECOWAS 2008), para 8.

${ }^{26}$ Ibid, para 9.

${ }^{27}$ Ibid, para 10.

${ }^{28}$ Ibid, para 13.

${ }^{29}$ Ibid, para 14.

${ }^{30}$ Ibid, para 15-16.

${ }^{31}$ Ibid, para 21.

${ }^{32}$ Ibid, para 22-23.
} 
Meanwhile, the plaintiff sued the Republic of Niger before the ECOWAS Court of Justice for violation of Articles 1, 2, 3, 5, 6, and 18(3) of the African Charter. ${ }^{33}$ Upon request of the plaintiff, the Court transferred its session to Niamey for hearing. ${ }^{34}$ Having regard to the Universal Declaration of Human Rights, the Convention on the Elimination of All Forms of Discrimination against Women, the Convention relating to Slavery, the Convention relating to the Abolition of Slavery, Slave Trade and Institutions and Practices Similar to Slavery, and the African Charter on Human and Peoples' Rights, the ECOWAS Court of Justice declared that the plaintiff was a victim of slavery and awarded her CFA $10,000,000 .{ }^{35}$ The Court blamed the defendant for inaction of its administrative and judicial authorities. ${ }^{36}$

In Registered Trustees of the Socio-Economic Rights \& Accountability Project (SERAP) $v$ Nigeria, the ECOWAS Court of Justice dealt with admissibility of a case brought against the Federal Republic of Nigeria by human rights non-governmental organisation registered under the laws of the defendant. The plaintiff alleged that Nigeria violated Articles 1, 2, 17, 21 and 22 of the African Charter. ${ }^{37}$ The ruling of the ECOWAS Court of Justice regarding jurisdiction was the following:

This court clearly has subject matter jurisdiction over human rights violations in so far as these are recognized by the African Charter on Human and Peoples' Rights, which is adopted by Article 4(g) of the Revised Treaty of ECOWAS. As the plaintiff's claim is premised on Articles 1, 2, 17, 21 and 22 of the African Charter on Human and Peoples' Rights, the Court does have subject matter jurisdiction of the suit filed by the plaintiff. ${ }^{38}$

After asserting its jurisdiction over the case, the Court held that "[i]t is trite law that this court is empowered to apply the provisions of the African Charter on Human and Peoples' Rights and Article 17 thereof guarantees the right to education. It is well established that the rights guaranteed by the African Charter on Human and Peoples' Rights are justiciable before this court". ${ }^{39}$ The ECOWAS Court of Justice has been acclaimed as the first international judicial

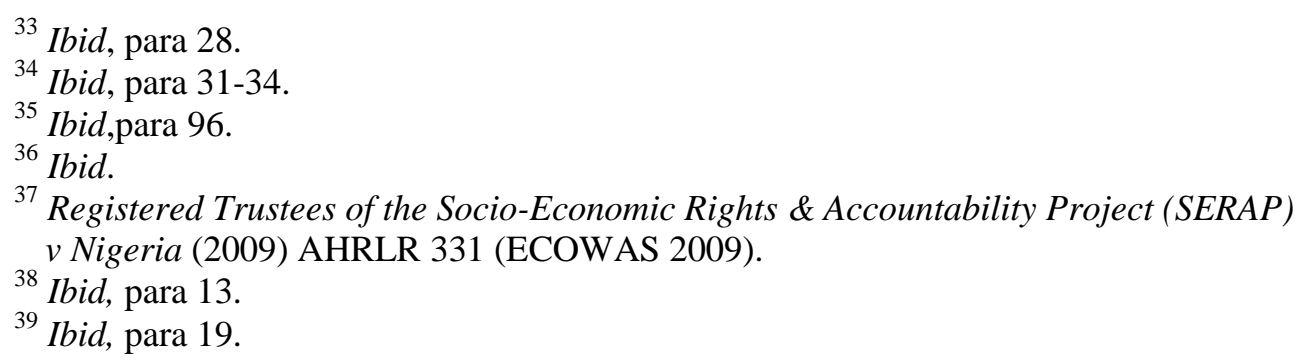


body to uphold justiciability of socio-economic rights because of its holding that the right to basic education is justiciable before it. ${ }^{40}$

\subsection{East African Court of Justice}

Cooperation among Kenya, Tanzania and Uganda dates back to the colonial era. In 1917, Kenya and Uganda formed Customs Union, and Tanzania (then Tanganyika) joined in $1927 .{ }^{41}$ The Customs Union was followed by the East African High Commission (1948-1961) and the East African Common Services Organisation (1961-1967). ${ }^{42}$ In 1967, the East African Community was established and took over the assets and liabilities of the East African Common Service Organisation. ${ }^{43}$ The East African Community lasted for ten years and became defunct in 1977 for various reasons. ${ }^{44}$ The businesspersons in Kenya put pressure on the government to withdraw. ${ }^{45}$ "Differences in economic policies and political approaches" were considered as reasons for the failure. ${ }^{46}$ The present East African Community (EAC) was re-launched in $1999 .{ }^{47}$ The areas of co-operation among members of EAC include political, social and cultural fields, research and technology, defence, security, and legal and judicial affairs. ${ }^{48}$ To achieve these objectives, the EAC Treaty sets out fundamental and operational principles that include the promotion and protection of human rights. $^{49}$

The East African Court of Justice (EACJ) is one of the seven organs that were established by EAC Treaty. ${ }^{50}$ It exercises the judicial function of the EAC through its first instance and appellate divisions. ${ }^{51}$ The EAC Treaty vests human

${ }^{40}$ Frans Viljoen 'The African Regional Human Rights System' in Catarina Krause \& Martin Scheinin (2012), International Protection of Human Rights: A Text Book (Turku: Institute for Human Rights, Åbo Akademi University), p. 555.

${ }^{41}$ History of the EAC: From Cooperation to Community, available at <http://www.eac.int/index.php?option=com_content\&view=article\&id=44\&Itemid=54>

${ }^{42}$ Ibid.

${ }^{43}$ Viljoen, supra note 1, p. 490.

${ }^{44}$ Ibid.

${ }^{45}$ Ibid

${ }^{46}$ Ibid

${ }^{47}$ Art 2(1) of Treaty Establishing East African Community, signed on 30 November 1999, came into force 7 July 2000, and amended on 14 December 2006 and 20

August 2007. The EAC Treaty was concluded among Kenya, Tanzania and Uganda. Rwanda and Burundi acceded to the Treaty on 18 June 2007. See also Viljoen, supra note 1, p. 490; Ruppel, supra note 3, p. 301.

${ }^{48}$ Art 5(1), EAC Treaty.

${ }^{49}$ Art 6(d) \& 7(2), EAC Treaty.

${ }^{50}$ Art 9(1), EAC Treaty.

${ }^{51}$ Art 9(1)(e) \& 23(2), EAC Treaty. 
rights jurisdiction in the EACJ, but postpones its operation until a future protocol authorises the commencement of the human rights jurisdiction. ${ }^{52}$

In Katabazi v Secretary-General of the East African Community, the Court was seized with a case in which Ugandan security personnel interfered with preparation of bail documents by surrounding Ugandan High Court and rearresting persons who were released on bail. ${ }^{53}$ The arrested persons were taken before a military General Court Martial which remanded them in custody. ${ }^{54}$ Although the Ugandan Constitutional Court ruled that the interference of the security personnel with the High Court was unconstitutional, the arrested persons were not released. ${ }^{55}$ The plaintiffs mainly invoked the violation of the EAC Treaty. The Court held that "jurisdiction with respect to human rights requires a determination of the Council and a conclusion of a Protocol to that effect." ${ }^{56}$ Since both of those steps did not take place, the Court held that "this Court may not adjudicate on disputes concerning violation of human rights per se. ${ }^{, 57}$ However, the Court has shown some judicial activism. ${ }^{58}$ It held that 'the intervention by the armed security agents of Uganda to prevent the execution of a lawful court order violated the principle of the rule of law. ${ }^{59}$ Actually, the EACJ upheld the right to liberty and claimed jurisdiction in human rights cases by framing its decisions in terms of treaty violations.

In East African Law Society v Attorney-General of Kenya, the applicant challenged the procedure of amending the EAC Treaty on the ground that it did not consult the people. ${ }^{60}$ Triggered by earlier decisions of the Court, the amendment modified the Court's structure by introducing an appellate division. The impact of the amendment was negative as it narrowed the jurisdiction of the Court and provided a time limit within which references by natural and judicial persons may be instituted before the Court. The Court held that 'the lack of people's participation in the impugned amendment process was inconsistent with the spirit and intendment of the Treaty. ${ }^{, 61}$ In essence, the Court upheld the

\footnotetext{
${ }^{52}$ Art 27 (2), EAC Treaty.

${ }^{53}$ Katabazi and Others $v$ Secretary-General of the East African Community and Another (2007) AHRLR 119 (EAC 2007), para 2.

${ }^{54}$ Ibid, para 3.

${ }^{55}$ Ibid,para 4.

${ }_{57}^{56} \mathrm{Ibid}$,para 34.

${ }^{57}$ Ibid.

${ }^{58}$ Solomon T Ebobrah (2009), 'Human rights development in sub-regional courts in Africa in 2008' African Human Rights Law Journal Vol. 9, p. 315.

${ }^{59}$ Katabazi case , supra note 53, para 54.

${ }^{60}$ East African Law Society and Others $v$ Attorney-General of Kenya and Others, Reference 3 of 2007 at 11.

${ }^{61}$ Ibid, p. 42.
} 
right to participation of the people which is guaranteed under Article 13 of the African Charter although it did not refer to the latter.

The protocol that would trigger the human rights jurisdiction of the EACJ was drafted in 2007 by the EAC Secretariat. ${ }^{62}$ However, it has not come into force yet. Recent developments in the region show that pressure was exerted on the EAC to expand the jurisdiction of the EACJ to cover human rights cases. ${ }^{63}$

\subsection{The SADC Tribunal}

The Southern Africa Development Co-ordination Conference, a loose association of states, was created in 1980 in Lusaka, Zambia. ${ }^{64}$ The Conference was transformed into the Southern African Development Community (SADC) in 1992 in Windhoek, Namibia. ${ }^{65}$ The state parties to the Treaty establishing SADC were aware of the need to observe human rights to involve their people in regional integration. ${ }^{66}$ The Treaty requires SADC and its Member States to act in accordance with "human rights, democracy and the rule of law. ${ }^{, 67}$ It establishes the SADC Tribunal along with seven other institutions. ${ }^{68}$

The SADC Tribunal is vested with the judicial power of the Community ${ }^{69}$ It was established to interpret the provisions of the SADC Treaty and its subsidiary instruments, ${ }^{70}$ with both contentious and advisory jurisdiction. ${ }^{71}$ The SADC Treaty and the Protocol on Tribunal and the Rules of Procedure thereof

${ }^{62}$ Solomon T Ebobrah (2010), 'Human rights developments in African sub-regional economic communities during 2009' African Human Rights Law Journal, Vol. 10, p. 240.

${ }^{63}$ Ibid.

${ }^{64}$ Munetsi Madakufamba (2007), 'SADC in the twenty-first century', Open Space: $a$ digest of Open Society Initiative for Southern Africa vol. 2 p. 90. See also Viljoen, supra note 1, p. 492.

${ }^{65}$ Mbugua Mureithi 'The Impact of regional courts in Africa in fostering regional integration and the development of international human rights jurisprudence' in George Mukundi Wachira (ed.) (2007), Judiciary Watch Report: Regional and Subregional Platforms for Vindicating Human Rights in Africa (Nirobi: Kenyan Section of International Commission of Jurists), p. 84; Madakufamba, supra note 64, p. 91.

${ }^{66}$ SADC Treaty, preamble.

${ }^{67}$ SADC Treaty, Art 4 (c).

${ }^{68}$ SADC Treaty, Art 9 (1).

${ }^{69}$ SADC Treaty, Art 9.

${ }^{70}$ SADC Treaty, Art 16(1); Art 14, Protocol on Tribunal and the Rules of Procedure thereof.

${ }^{71}$ SADC Treaty, Art 16(1) \& (4). 
do not provide that the Tribunal has jurisdiction on specific disputes ${ }^{72}$ nor do they exclude from the jurisdiction of the Tribunal any dispute under any field of law. ${ }^{73}$

To ascertain the Tribunal's jurisdiction over a given dispute, one needs to examine whether SADC has legal instruments that govern the area of the dispute, because the Tribunal has jurisdiction over instruments applicable in SADC. ${ }^{74}$ The Tribunal has jurisdiction over human rights because SADC has human rights instruments that include the Charter of Fundamental Social Rights and the Protocol on Gender and Development. The Tribunal itself confirmed that it has jurisdiction on human rights in Mike Campbell (Pvt) Limited $v$ Zimbabwe. ${ }^{75}$

In the Campbell case, the SADC Tribunal entertained a case in which the government of Zimbabwe compulsorily acquired agricultural land on the basis of constitutional amendment that vests ownership of acquired land in the State of Zimbabwe and sets aside the jurisdiction of courts to question the legality of such compulsory acquisition. The agricultural lands were mainly acquired from white owners who, for reasons attributable to colonial history, happened to own large tracts of land suitable for agriculture. The applicants submitted that the enactment and implementation of the constitutional amendment violated the SADC Treaty. They also alleged that they were denied access to justice and compensation for their land as well as equal treatment. The respondent state challenged the jurisdiction of the Tribunal over the matters. In confirming its jurisdiction, the Tribunal relied on Article 21(b) (the Protocol on Tribunal and Rules of Procedure Thereof) which requires reference to 'treaties, general principles and rules of public international law and any rules and principles of the law of States.' The Tribunal held that it 'has jurisdiction in respect of any dispute concerning human rights, democracy and the rule of law. ${ }^{.76}$

According to some commentators, the SADC Tribunal has competence to interpret even non-SADC instruments. ${ }^{77}$ The subject-matter jurisdiction of the

${ }^{72}$ See generally the SADC Treaty; The Protocol on Tribunal and the Rules of Procedure Thereof, adopted on 7 August 2000 in Windhoek, Namibia by the SADC Heads of State and Government and entered into force on 14 August 2001, reproduced in Ebobrah \& Tanoh, supra note 6, p. 375.

${ }^{73}$ Compare art 27 (2), EAC Treaty where the Treaty confers human right jurisdiction on the court and suspends it.

${ }^{74}$ See Article 16 of SADC Treaty and Article 14 of the Protocol on Tribunal and the Rules of Procedure Thereof.

${ }^{75}$ Mike Campbell (Pvt) Limited and Others $v$ Zimbabwe (2008) AHRLR 199 (SADC 2008).

${ }^{76}$ Ibid, para 32.

${ }^{77}$ Mmatsie Mooki 'African regional courts and their role in the promotion and protection of human rights: The Southern African Development Community 
SADC Tribunal "clearly covers human rights issues, including the interpretation and application of the African Charter. ${ }^{, 78}$ The Tribunal seems to have concurred with this view in the Campbell case. It "first referred to Article 21(b) which, in addition to enjoining the Tribunal to develop its own jurisprudence, also instructs the Tribunal to do so 'having regard to applicable treaties, general principles and rules of public international law' which are sources of law for the Tribunal". ${ }^{79}$ In this holding, the Tribunal made it clear that its sources of law are not limited to SADC instruments. Rather, the Tribunal situated itself in a position similar to the African Court on Human and Peoples' Rights. ${ }^{80}$ Thus, the African Charter and other treaties are sources of law for the SADC Tribunal.

Campbell and other cases brought against Zimbabwe seem to have boomeranged on the very existence of the SADC Tribunal. Because of the Tribunal's holding in that case, Zimbabwe questioned the legality of the SADC Tribunal. ${ }^{81}$ As a result, the SADC Summit first refused to fill vacancies on the Tribunal and subsequently suspended the Tribunal at the 2010 SADC Summit. ${ }^{82}$ Although the Summit has the power to amend SADC Treaty, the procedure it followed in suspending the Tribunal was ultra vires. ${ }^{83}$

Tribunal' in George Mukundi Wachira (ed) (2007), Judiciary Watch Report:

Regional and Sub-regional Platforms for Vindicating Human Rights in Africa

(Nirobi: Kenyan Section of International Commission of Jurists), p. 39. Mooki

concluded that the use of treaties which promotes and protects human rights by the

SADC Tribunal is inevitable. Chidi Anselm Odinkalu 'Complementarity,

Competition or Contradiction: The Relationship between the African Court on Human and Peoples' Rights and Regional Economic Courts in East and Southern Africa'

(Unpublished) (Presentation to Conference of East and Southern African States on the

Protocol Establishing the African Court on Human and Peoples' Rights, Gaborone,

Botswana, 9-10 December 2003) at

<http://www.africancourtcoalition.org/images/docs/research-

papers/chidioncomplementarity.pdf> (accessed on 13 November 2011).

${ }^{78}$ Odinkalu, Ibid, p. 9.

${ }^{79}$ Campbell case, supra note 75 , para 31.

${ }^{80}$ Compare Art 7, Protocol to the African Charter on Human and People's Rights on the establishment of an African Court on Human and People's Rights, adopted in Addis Ababa, Ethiopia, on 10 June 1998, OAU DOC. OAU/LEG/EXP/AFCHPR/PROT (III). Art 7 empowers the African Court to apply the provisions of the African Charter and any other relevant human rights instruments ratified by the States concerned.

${ }^{81}$ Viljoen (2012), supra note 40, p. 556.

${ }^{82}$ Ibid; Solomon T Ebobrah (2012), 'Human rights developments in African subregional economic communities during 2011' 12 African Journal of Human Rights Law 223, Vol. 12, p. 225.

83 'SADC Tribunal Dissolved by Unanimous Decision of SADC Leaders', Speech by Ariranga G. Pillay, Former President of SADC Tribunal, available at 
On 17 August 2012, the SADC Summit disbanded the Tribunal and directed SADC Ministers of Justice and Attorneys-Generals to negotiate a new protocol in order to reconstitute the Tribunal with a fresh mandate. ${ }^{84}$ The mandate of a new tribunal will be "confined to interpretation of the SADC Treaty and Protocols relating to disputes between Member States. ${ }^{85}$

Civil society organisations are campaigning against the decision of the SADC Summit that disbanded the Tribunal. Part of their campaigning activities includes resorting to continental human rights bodies: the African Commission and the African Court. The African Commission has accepted the admissibility of a communication about the decision of the SADC leaders to suspend the Tribunal. ${ }^{86}$ The communication has been submitted on behalf of Zimbabwean farmers, and all 15 SADC leaders have been cited as respondents. ${ }^{87}$ Pan African Lawyers Union and Southern Africa Litigation Centre have requested advisory opinion from the African Court on the legality of suspending the SADC Tribunal. ${ }^{88}$

\section{Admissibility of Pending or Decided Cases in General}

Some international human rights bodies do not admit cases that are pending before other international judicial or quasi-judicial organs. International human rights instruments treat such cases as simultaneously duplicating procedures (pendente lite). Other human rights bodies do not admit cases that have already been decided or settled, and there are bodies that do not admit both pending and decided cases.

The first category of international human rights bodies prohibits only simultaneously duplicating procedures. They may admit cases or communications that have already been decided under another procedure of international investigation or settlement. An example of this type of human rights body is the

\footnotetext{
<http://www.osisa.org/sites/default/files/article/files/Speech\%20by\%20former\%20Pr esident\%20of\%20SADC\%20Tribunal.pdf> (accessed on 6 February 2013).

${ }^{84}$ Zvamaida Murwira 'Southern Africa: Regional Leaders Permanently Disband SADC

Tribunal' 21 August 2012 All Africa, <available at $<$ http://allafrica.com/stories/201208210893.html>.

85 'Southern African Development Community: SADC Tribunal', available at $<$ http://www.sadc.int/about-sadc/sadc-institutions/tribun/>

${ }^{86}$ Richard Lee 'African Commission to hear SADC Tribunal case' 22 November 2012, available at <http://www.osisa.org/law/regional/african-commission-hear-sadctribunal-case >

${ }^{88}$ Richard Lee 'African Court asked to rule on SADC Tribunal' 22 November 2012, available at <http://www.osisa.org/law/regional/african-court-asked-rule-sadctribunal>.
}

${ }^{87}$ Ibid. 
United Nations Human Rights Committee. ${ }^{89}$ Under Article 5(2)(a) of the Optional Protocol to the International Covenant on Civil and Political Rights, the Human Rights Committee does not consider an individual communication unless it has ascertained that 'the same matter is not being examined under another procedure of international investigation or settlement. ${ }^{90}$

In Fanali v Italy, the Human Rights Committee entertained a communication alleging violation of the right to appeal contrary to Article 14(5) of the ICCPR. ${ }^{91}$ The author of the communication along with other defendants was tried and sentenced before the Constitutional Court of Italy. His co-defendants submitted complaints to the European Commission of Human Rights while the author did not. Since the respondent State made reservation under Article 5(2)(a) of the Optional Protocol, it argued that the communication was inadmissible as the same matter was being examined before the European Commission of Human Rights. The Human Rights Committee rejected the respondent's argument and defined 'the same matter' as 'including the same claim concerning the same individual, submitted by him or someone else who has the standing to act on his behalf before the other international body. ${ }^{92}$ Although it did not find violation, the Committee found the communication admissible.

In O.F. $v$ Norway, the Human Rights Committee was seized with a communication against Norway for violation of Article 14 of the International Covenant on Civil and Political Rights (ICCPR). ${ }^{93}$ Although the case was submitted to the European Commission of Human Rights, it was rejected since it was not submitted within six months from the time of exhaustion of local remedies. While considering admissibility of the communication, the Human Rights Committee accepted Norway's argument that 'Article 5(2)(a) [of the Optional Protocol] prevents simultaneous duplicating procedures.' Since the European Commission of Human Rights did not examine the communication,

${ }^{89}$ Other example include the Inter-American Commission on Human Rights under art 46(1)(c) of the American Convention on Human Rights, adopted by the InterAmerican Specialised Conference on Human Rights on 22 of November 1969 at San José, entered into force on 18 July 1978.

${ }^{90}$ Art 5(2)(a) of Optional Protocol to the International Covenant on Civil and Political Rights, adopted by General Assembly resolution 2200A (XXI) of 16 December 1966, entered into force on 23 March 1976.

${ }^{91}$ Communication No. 75/1980, Fanali v Italy adopted on 31 March 1983 at eighteenth session of Human Rights Committee in International Covenant on Civil and Political Rights: Selected Decisions of the Human Rights Committee under the Optional Protocol CCPR/C/OP/2 Vol 2 para 7.2, p. 100.

${ }^{92} \mathrm{Ibid}$, para 7.2 at 100 .

${ }^{93}$ Communication No. 158/1983, O. F. v Norway (Human Rights Committee) (twentythird session) 26 October 1984 CCPR/C/OP/2. 
the Human Rights Committee did not reject it on the grounds of prior examination. Rather, the Committee's finding of inadmissibility was based on the author's failure to substantiate his or her communication.

Through reservation, some countries exclude the Human Rights Committee from examining communications in which 'the same matter has already been examined under other procedures of international investigation or settlement. ${ }^{94}$ Where such reservation exists, the Human Rights Committee does not admit communications pending before or decided by other international tribunals. Such reservation "sets forth the principle of non bis in idem. ${ }^{95}$ This principle bars blaming a state twice for the same violation.

Among African countries, only Uganda made similar reservation under the ICCPR. ${ }^{96}$ The reservation precludes the Human Rights Committee from reviewing cases against Uganda that have already been decided by subregional and regional judicial or quasi-judicial bodies such as the East African Court of Justice, African Commission, the African Court or the African Committee of Experts on the Rights and Welfare of the Child.

The second category of human rights bodies does not admit a case that has already been decided although they admit a case that is pending before other international bodies. Unlike the first category, simultaneously duplicating procedures are allowed under this category. The advantage of such a requirement is to avoid the "unsettling possibility of divergent "conclusions" to a particular matter before different bodies. ${ }^{97}$

\footnotetext{
94 These countries Austria, Croatia, Denmark, France, Germany, Iceland, Ireland, Italy, Luxembourg, Malta, Norway, Poland, Romania, Russia, Slovenia, Spain, Sweden, Turkey, Uganda, El Salvador, Moldova, and Sri Lanka. They are mostly European countries. See Reservation under the Optional Protocol to ICCPR, available at $<$ http://treaties.un.org/Pages/ViewDetails.aspx?src=TREATY\&mtdsg_no=IV$5 \&$ chapter=4\&lang=en\#2Some $>$ (accessed on 11 February 2013).

${ }^{95}$ O.F. v Norway.

${ }^{96}$ Frans Viljoen 'Communications under the African Charter: Procedure and Admissibility' in Malcolm Evans \& Rachel Murray (eds) (2008), The African Charter on Human and Peoples' Rights: the System in Practice 1986-2006 (Cambridge: Cambridge University press), p. 127. The reservation provides that 'Uganda does not accept the competence of the Human Rights Committee to consider a communication under the provisions of article 5 paragraph 2 from an individual if the matter in question has already been considered under another procedure of international investigation or settlement.' See $<$ http://treaties.un.org/Pages/ViewDetails.aspx?src=TREATY\&mtdsg_no=IV$5 \&$ chapter $=4 \&$ lang $=$ en\#EndDec $>$ (accessed on 7 February 2013).

${ }^{97}$ Ibid, p. 126.
} 
The African Commission and the African Court belong to this category. ${ }^{98}$ Article 56(7) of the African Charter precludes the African Commission from dealing with 'cases which have been settled.' However, the decisions of the African Commission do not seem consistent on this issue. For example, the African Commission, contrary to Article 56(7) of the African Charter, declared a communication inadmissible on the ground that it 'had already been referred for consideration to the Human Rights Committee' in Mpaka-Nsusu v Zaire. ${ }^{99}$ Although it does not come out from the records of the case, it may be surmised that the African Commission had learned reference of the case to the Human Rights Committee from submissions of the respondent state.

In another communication, the African Commission proceeded to consider a communication that had already been submitted to the Working Group of the United Nations Sub-Commission on the Prevention of Discrimination and Protection of Minorities in Njoku $v$ Egypt. ${ }^{100}$ The respondent challenged admissibility of the communication under Article 56(7) of the Charter. Rejecting the argument of the respondent, the Commission held that:

[Article 56(7)] talks about 'cases which have been settled ...' It is therefore of the view that the decision of the United Nations Sub-Commission not to take any action and therefore not to pronounce on the communication submitted by the complainant does not boil down to a decision on the merits of the case and does not in any way indicate that the matter has been settled as envisaged under Article 56(7) of the African Charter on Human and Peoples' Rights. The Commission therefore rejected the arguments of the defendant.

The African Court decides on 'the admissibility of cases taking into account the provisions of Article 56 of the Charter. ${ }^{101}$ By referring to Article 56 of the

\footnotetext{
${ }^{98}$ See art 6(2) of the Protocol to the African Charter on Human and Peoples' Rights on the Establishment of an African Court on Human and Peoples' Rights. This provision refers to art 56 of the African Charter. Other example include art 35 of European Convention for the Protection of Human Rights and Fundamental Freedoms as amended by Protocol No. 11, signed by the Members of the Council of Europe on 4 November 1950 at Rome, entered into force on 3 September 1953.

${ }^{99}$ Mpaka-Nsusu v Zaire (2000) AHRLR 71 (ACHPR 1994), para 3-4.

${ }^{100}$ Njoku v Egypt (2000) AHRLR 83 (ACHPR 1997), para 56. The Commission did not consider the matter settled as the Working Group of the United Nations SubCommission on the Prevention of Discrimination and Protection of Minorities did not decide on the merit of the decision.

${ }^{101}$ Protocol on the African Court, Art 6(2). It should be noted that the wording of Art 6(2) of the Protocol gives more lee ways to the African Court. The Court need not strictly apply the provision of art 56(7). But the African Commission has no such lee ways. See Viljoen (2007), supra note 1, p. 448.
} 
African Charter, the establishing Protocol places the African Court in a similar position as the African Commission regarding admissibility of pending or decided cases and that position was confirmed in Rule 40(7) of the Rules of the African Court. ${ }^{102}$

The third category of human rights bodies does not admit cases that are pending before or have already been decided by other tribunals. For example, the Optional Protocol to the Convention on the Elimination of Discrimination against Women (OP-CEDAW) precludes the Committee on the Elimination of Discrimination against Women from examining a communication in which 'the same matter has already been examined by the Committee or has been or is being examined under another procedure of international investigation or settlement. ${ }^{103}$ Thus, OP-CEDAW and other similar human rights instruments prohibit pendente lite and establish the principle of non bis in idem. ${ }^{104}$

\section{Reasons for the Inadmissibility of Cases Decided by Subregional Courts}

\subsection{Threat of Massive Backlog and Wise Use of Resources}

Human rights treaty bodies consider communications or cases that comply with admissibility requirements. The requirements serve as screening mechanisms between national and international institutions or among international institutions. ${ }^{105}$ There is an apprehension that the absence of such screening

${ }^{102}$ African Court on Human and Peoples' Rights, Rules of Court, adopted and entered into force on 2 June 2010, rule 40(7).

${ }^{103}$ Optional Protocol to the Convention on the Elimination of Discrimination Against Women, adopted by UN General Assembly in resolution A/54/4 on 6 October 1999 at New York and entered into force on 22 December 2000.

104 Other examples include Art 3(2)(c) of Optional Protocol to the International Covenant on Economic, Social and Cultural Rights adopted on 10 December 2008 by the General Assembly resolution A/RES/63/117; Art 30(2)(e) International Convention for the Protection of All Persons from Enforced Disappearance, adopted by General Assembly resolution 61/177 of 20 December 2006; Art 2(c) of the Optional Protocol to the Convention on the Rights of Persons with Disabilities adopted by General Assembly resolution 61/106 of 13 December 2006; Art 22(5)(a) of Convention Against Torture and Other Cruel, Inhuman or Degrading Treatment or Punishment, adopted by the UN General Assembly in resolution 39/46 of 10 December 1984 at New York, entered into force on 26 June 1987; Art 77(3)(a) of International Convention on the Protection of the Rights of All Migrant Workers and Members of Their Families, adopted by General Assembly resolution 45/158 of 18 December 1990, entered into force on 1 July 2003.

${ }^{105}$ Some admissibility requirements (eg exhaustion of local remedies) serve as filtering mechanisms between national and international mechanisms. See Viljoen (2008), 
mechanisms overburdens international institutions with cases. ${ }^{106}$ Article 56(7) of the African Charter serves as a screening mechanism between the African Commission or the African Court and other international institutions. It is submitted that Article 56(7) of the African Charter can serve the purpose of reducing the number of cases that come to the African Commission and the African Court.

Both the African Commission and the Court do not have sufficient time and resources to deal with a massive number of cases. The African Commission is a part-time body. ${ }^{107}$ It carries out its mandate in ordinary and extraordinary sessions. ${ }^{108}$ The ordinary sessions of the Commission are held at least twice a year and they last for about two weeks unless the African Commission decides to reduce or extend the duration. ${ }^{109}$ The Chairperson of the African Commission may convene extraordinary sessions when requested by the majority of the commissioners or by the Chairperson of the African Union Commission. ${ }^{110}$

As a part-time body, the African Commission does not have sufficient time to carry out its functions. A perusal of its activity reports reveals that the Commission keeps postponing a large number of communications from one session to another. For example, on its $45^{\text {th }}$ Ordinary Session held from 13 to 27 May 2009, the Commission deferred to the next session 71 out of 80 communications tabled for the Commission, among others, owing to time constraints. ${ }^{111}$ On its $46^{\text {th }}$ Ordinary Session held from 11 to 25 November 2009, it deferred 62 communications for similar reasons. ${ }^{112}$ Although the Commission managed to hold the $7^{\text {th }}$ Extraordinary Session from 5 to 12 October 2009 between ordinary sessions, the backlog reduced only by nine communications.

supra note 96, p. 88 . The admissibility requirement that a communication must have not been settled by another procedure of international investigation or settlement serves as screening mechanisms between international institutions.

${ }^{106}$ Viljoen (2008), Ibid, p. 88.

${ }^{107}$ Viljoen (2007), supra note 1, p. 315.

${ }^{108}$ Rules of Procedure of the African Commission on Human and Peoples' Rights, approved by the African Commission on Human and Peoples' Rights during its 47th

109 Ibid, Rule 26. ordinary session held in Banjul, The Gambia from May 12 to 26, 2010, Rule 25.

${ }^{110}$ Ibid, Rule 27(2).

111 26th Activity Report of the African Commission on Human and Peoples' Rights (ACHPR) submitted in Accordance With Article 54 of the African Charter on Human and Peoples' Rights, submitted to African Union Executive Council, Fifteenth Ordinary Session, 24 - 30 June 2009, Sirte, Libya , EX.CL/529(XV), para 141.

112 27th Activity Report of the African Commission on Human and Peoples' Rights (ACHPR) submitted in Accordance with Article 54 of the African Charter on Human and Peoples' Rights, para 209. 
For similar reasons, 74 communications were deferred in its $47^{\text {th }}$ Ordinary Session held from 12 to 26 May 2010, and other 74 communications were deferred in the $48^{\text {th }}$ Ordinary Session held from 10 to 24 November $2010 .{ }^{113}$

Lack of human and financial resources has undermined the capacity of the African Commission to resolve its mounting backlog. The Commission has consistently been complaining about lack of support staff at its secretariat. On its $47^{\text {th }}$ Ordinary Session, for instance, the Executive Secretary reported that 'high staff turnover, combined with the [Commission's] chronic understaffing, are some of the factors that lie at the heart of the challenges confronting the [Commission] in its processing and consideration of communications." 114 Although the Executive Secretary reported improvements on the $48^{\text {th }}$ Ordinary Session, the report to the $49^{\text {th }}$ Ordinary Session shows that the staffing problem was very critical and that it was no longer possible for the Secretariat to provide the African Commission with 'the support which it needed to function effectively and deliver on the mandate entrusted to it. ${ }^{115}$ The problem of understaffing is mainly attributed to the lengthy process of the African Union Commission's Human Resource Department. ${ }^{1}$

The African Commission consists of 11 members. ${ }^{117}$ Compared with its counterpart in the Inter-American system which consists of only seven members, 11 commissioners seem to be high. ${ }^{118}$ With a lesser number of commissioners, the Inter-American Commission on Human Rights is more productive than the African Commission. ${ }^{19}$ While the Inter-American Commission annually receives more than 1,500 petitions, the African Commission receives less than one per cent of that. ${ }^{120}$ Still, 11 commissioners are said to be insufficient to adequately implement the mandate of the African

113 28th Activity Report of the African Commission on Human and Peoples' Rights (ACHPR), submitted to AU Executive Council, Seventeenth Ordinary Session 19 23 July 2010, Kampala, Uganda, EX.CL/600(XVII), para 212; 29th Activity Report of the African Commission on Human and Peoples' Rights (ACHPR), submitted to AU Executive Council, Nineteenth Ordinary Session 23-28 June 2011, Malabo, Equatorial Guinea, EX.CL/678(XIX), 184.

$11428^{\text {th }}$ Activity Report, supra note 113, para 193.

$11529^{\text {th }}$ Activity Report, supra note 113 , para 224.

${ }^{116}$ Magnus Killander \& Adem K Abebe(2012), 'Human rights developments in the African Union during 2010 and 2011' African Journal of Human Rights Law 199, Vol. 12, at 201.

${ }^{117}$ African Charter, Article 31.

${ }^{118}$ American Convention on Human Rights adopted at the Inter-American Specialized Conference on Human Rights, San José, Costa Rica, 22 November 1969 and entered into force on 18 July 1978; O.A.S.T.S. 36; 1144 U.N.T.S. 123, art 34.

${ }^{119}$ Killander \& Abebe, supra note 116.

${ }^{120}$ Ibid. 
Commission. ${ }^{121}$ In 2006, it was recommended that the number of commissioners be increased from 11 to between 15 and $18 .{ }^{122}$

The African Commission had been under-resourced in the past. ${ }^{123}$ It relied on outside sources for most of its works. ${ }^{124}$ Such dependence on outside sources subjected the Commission to serious criticisms that it was being manipulated by donors. ${ }^{125}$ Recently, financial resources of the Commission have been showing improvements. Since 2008, the Commission presents and defends its budget. ${ }^{126}$ The Commission's budget for the 2013 Financial Year stands at 8.5 million US Dollars (US \$ 8,488,716). ${ }^{127}$

Likewise, the African Court does not have much time as the judges perform their functions on a part-time basis. ${ }^{128}$ The Court holds only four ordinary sessions a year. ${ }^{129}$ The Court may hold extraordinary sessions which may be convened by the President of the Court or at the request of a majority of members of the Court. ${ }^{130}$ Since there are no strict rules providing for a maximum number of extraordinary sessions to be held in a year, the Court can be flexible and hold more extraordinary sessions when there are more tasks. Nevertheless, it lacks the mandate to operate as a permanent judicial body.

A discussion on the admissibility of subregional courts' decision before the African Commission would have been pointless had access to the African Court been open to individuals and NGOs. It is only the African Commission, state parties and African intergovernmental organisations that have direct access to the Court. ${ }^{131}$ Even the African Committee of Experts on the Rights and Welfare of the Child is omitted from the list of organs that have direct access to the Court although one may argue that it falls under African intergovernmental

${ }^{121}$ Report of the Brainstorming meeting on the African Commission, on Human and Peoples' Rights: 9-10 May 2006, Corinthia Atlantic Hotel, Banjul, The Gambia, Twentieth Activity Report of the African Commission on Human and Peoples' Rights, Annex II.

122 Ibid.

${ }^{123}$ Viljoen (2007), supra note 1, p. 315.

${ }^{124}$ Ibid.

${ }^{125}$ Ibid.

${ }^{126}$ Japhet Biegon \& Magnus Killander (2009), 'Human rights developments in the African Union during 2008' African Journal of Human Rights Law 295, Vol. 9, at 297.

${ }^{127}$ AU Executive Council, Decision on the Budget of the African Union for the 2013 Financial Year, Doc. EX.CL/721(XXI).

${ }^{128}$ Protocol on the African Court, art 15(4).

${ }^{129}$ African Court on Human and Peoples' Rights, Rules of Court, adopted and entered into force on 2 June 2010, Rule 14.

${ }^{130}$ Ibid, rule 15.

${ }^{131}$ Protocol on the African Court, Art 5(1). 
organisations. ${ }^{132}$ So far, few African states have made declarations under Article 34(6) of the Protocol establishing the African Court to allow individuals and NGOs to submit cases directly to the African Court. ${ }^{133}$

The African Commission will, therefore, remain the major organ through which human rights cases are submitted to the African Court. The Commission's referral of cases is discretionary. Its Rules of Procedures provide for three illustrative instances of seizing the African Court with cases. ${ }^{134}$ First, the African Commission submits a case to the African Court when a respondent state fails to implement its recommendations that have been considered by the Assembly of Heads of State and Government of the African Union within 180 days. ${ }^{135}$

Second, the African Commission may refer a case to the African Court when a respondent state fails to comply with provisional measures. ${ }^{136}$ The African Charter is silent on provisional measures. However, the African Commission may order provisional measures to prevent irreparable damage to victims of human rights violations on the basis of its Rules of Procedures. ${ }^{137}$ The Commission has developed the practice of granting provisional measures. ${ }^{138}$

Third, the African Commission may submit a case that "constitutes serious or massive violations of human rights. ${ }^{139}$ Besides, the Commission has an obligation to refer such cases to the Assembly of Heads of State and Government. ${ }^{140}$ In 2011, the African Commission made its first reference under this rule in African Commission on Human and Peoples' Rights v Great Socialist Libyan Arab Jamahiriya. ${ }^{141}$ The Commission filed an application before the African Court on the basis of several communications that it received following the 2011 uprising against Mummar Qadafi's regime in Libya. In its

${ }^{132}$ Compare Statute of the African Court of Justice and Human Rights, art 30(c). The Committee is listed as one of the organs having direct access before the African Court of Justice and Human Rights.

${ }^{133}$ Only Burkina Faso, Ghana, Malawi, Mali and Tanzania had mad declaration under article 34(6). See I de Meyer 'Chart of ratifications: AU human rights treaties, Position as at 30 April 2012' (2012) African Human Rights Law Journal, Vol. 12, p. 308.

134 African Commission Rules of Procedures, Rule 118.

${ }^{135}$ Ibid, Rules 112(2) \& 118(1).

${ }^{136}$ Ibid, Rules 98 \& 118(2).

${ }^{137} \mathrm{Ibid}$, Rule 98(1).

${ }^{138}$ See, for example, International Pen and Others (on behalf of Saro-Wiwa) v Nigeria (2000) AHRLR 212 (ACHPR 1998), para 8-9; Interights and Others (on behalf of Bosch) v Botswana (2003) AHRLR 55 (ACHPR 2003), para 10.

${ }^{139}$ Ibid, rule $118(3)$.

${ }^{140}$ African Charter, Article 58.

${ }^{141}$ African Commission on Human and Peoples' Rights $v$ the Great Socialist Libyan People's Arab Jamahiriya, Application No. 004/2011, ruling 2 September 2011. 
submission as an applicant, the Commission alleged that violent suppression of demonstration by aerial bombardment and excessive use of heavy weapons and machine guns against the population resulting in death and injuries amounts 'to serious violations of the right to life and to the integrity of persons, freedom of expression, demonstration and assembly. ${ }^{142}$ The Court ordered provisional measures against Libya on its own motion as the Commission did not make a request to that effect. ${ }^{143}$

As long as direct access to the African Court by individuals and NGOs is limited and the Commission's referral of cases remains discretionary, the solution to the massive backlog before the African Court is a distant possibility. Even more so, individuals and NGOs may bring cases that have already been decided by subregional courts to the African Commission with the hope of accessing the African Court. One may also optimistically assume that many African states will make declarations to allow individuals and NGOs to access the African Court. Under either scenario, there would be pressure on the resources of the African Court and the African Commission.

Africa should thus prudently use its regional human rights institution and scarce resources. Africans need to learn a lesson from the European Court of Human Rights, which has become 'a victim of its own success' in recent years as it 'faces a docket crisis of massive proportions.' ${ }^{144}$ Narrowing the admissibility criteria has been taken as one of the steps to reform the European Court. ${ }^{145}$ It is, therefore, submitted that the African Commission and the African Court should not admit cases decided by subregional courts because such cases unnecessarily consume their scarce time and resources.

Any assumption that sub-regional courts might be subject to more local interests and open to manipulation is not supported by evidence. This assumption is not plausible because experience, on the contrary, shows that neighbouring countries are more concerned about human rights violations at their doorsteps. In fact, African governments with records of human rights violations rather incline towards opposing the human rights jurisdiction of subregional courts. These courts have been a challenge to states in the subregions. As evidenced by restructuring of East African Court of Justice and suspension of the SADC Tribunal, various African states are reacting to the

\footnotetext{
${ }^{142}$ Ibid, para 2.

${ }^{143}$ Ibid, para 9.

${ }^{144}$ Laurence R Helfer (2008), 'Redesigning the European Court of Human Rights: Embeddedness as a deep structural principle of the European human rights regime' The European Journal of International Law 125, Vol. 19, p. 125.

${ }^{145}$ Philip Leach (2009), 'On reform of the European Court of Human Rights' European Human Rights Law Review 725, Vol. 6, p. 728.
} 
decisions of subregional courts by amending their constitutions or taking other decisions. The assumption does not thus justify the admissibility of subregional courts' decisions before the African Commission or African Court.

\subsection{Finality of Subregional Courts' Decisions}

International $^{146}$ courts or tribunals are usually empowered to render final and binding decisions no matter how different their subjects of jurisdiction are. A perusal of instruments establishing international courts and tribunals reveals that the finality of their decisions does not depend on the number of states party to the constituting instrument or on the permanent or temporary nature of the court or tribunal. For example, the Statute of the International Court of Justice (ICJ), to which almost all states are party, provides that the judgement of the Court is 'final and without appeal. ${ }^{147}$ The 2000 Algiers Peace Agreement which was concluded between Ethiopia and Eritrea at the end of Ethio-Eritrean war can be another example. ${ }^{148}$ Article 5(17) of this Agreement establishes a neutral Claims Commission, a temporary arbitral tribunal, and provides that the decision of the Commission is 'final and binding.'

The Treaties establishing subregional courts in Africa are no exception. They provide that the decisions of these courts are final and binding. ${ }^{149}$ These treaties foreclose any appeal from subregional courts to regional bodies like the African Commission and the African Court, or any other global courts and tribunals such as the ICJ. A concern raised in this regard is that 'it may be desirable to give room for reference of cases from' subregional courts as these courts are not 'specifically established for the purpose of human rights protection. ${ }^{150}$

${ }^{146}$ The word 'international' is used here to mean 'connected with or involving more than one [state].' See A S Hornby Oxford Advanced Learner's Dictionary of Current English (2000) 680. It refers to all supra national institutions whether they are subregional, regional or global.

${ }^{147}$ Art 60 of the Statute of International Court of Justice.

${ }^{148}$ Peace Agreement between the Government of the Federal Democratic Republic of Ethiopia and the Government of the State of Eritrea signed in Algiers, Algeria on 12 December 2000 available at $<$ http://server.nijmedia.nl/pcacpa.org/showfile.asp?fil_id=1030> (accessed on 13 November 2011).

${ }^{149}$ Art 76(2) of the Revised ECOWAS Treaty provides that the decision of the ECOWAS Community Court 'shall be final and shall not be subject to appeal; Art 16(5) of SADC Treaty provides that 'the decisions of the Tribunal shall be final and binding.' Art 35(1) of the Treaty Establishing the East African Community stipulates that the judgment of the Community Court is 'final, binding and conclusive and not open to appeal.' Art 31(1) the COMESA Treaty provides that the judgment of the COMESA Court is 'final and conclusive and not open to appeal.'

${ }^{150}$ Solomon T Ebobrah (2009), 'The admissibility of cases before the African Court on Human and Peoples' Rights: who should do what?' Malawi Law Journal 87, Vol. 3, p. 98. 
Although a reference from subregional courts to the African Court may ensure a uniform interpretation of the African Charter, it overburdens the Court. Besides, there is no sufficient legal basis for making such references. Member states of RECs, subregional courts and other organs of RECs are bound by the provisions of their treaties according to which decisions of subregional courts are final and binding. Thus, their reference from subregional courts' decision would be violation of treaties establishing these courts.

An inter-state reference from decisions of subregional courts, albeit unlikely, may be made by a state party to the African Charter (which is not a member of a particular REC) against another state party (which is a member of a particular REC). For example, Kenya which is not a member state of ECOWAS may refer an inter-state complaint to the African Court against, say, Ghana which is a member state of ECOWAS. In such scenarios, the state making reference would not be bound by the finality clause. Yet such reference would encounter the defence of res judicata as discussed below. Treaties establishing subregional courts do not also bind individuals and NGOs. However, their reference to the African Court will not fulfil admissibility requirement under Article 56(7) of the African Charter as discussed below.

\subsection{Prohibition of Double Jeopardy}

In Common Law legal system, double jeopardy means 'the fact of being prosecuted twice for substantially the same offense. ${ }^{, 151}$ The corresponding term in civil law legal system is non bis in idem. ${ }^{152}$ An accused person faced with the risk of double jeopardy can raise the plea of autrefois acquit or autrefois convict. Autrefois acquit is 'a plea by a person indicted for a crime for which he or she had previously been tried and acquitted' while autrefois convict is 'a plea by a person indicted for a crime for which he or she had previously been tried and convicted. ${ }^{153}$ The principle that a person should not be prosecuted twice for the same crime is recognised as a human rights principle. ${ }^{154}$

${ }^{151}$ Bryan A. Garner (ed.) (2000), Black's Law Dictionary (St. Paul: West Group), p. 506.

${ }^{152}$ See Garner, supra note 151, p. 1665. The legal maxim 'non bis in idem' or its imperative 'ne bis in idem' literally means 'not twice for the same thing.' The maxim expresses the principle that 'a person shall not be twice tried for the same crime.'

${ }^{153}$ Susan Ellis Wild (ed) (2006), Webster's New World Law Dictionary (Hoboken: Wiley Publishing, Inc.) p. 38.

${ }^{154}$ See art 14(7) of ICCPR. See Nihal Jayawickrama (2002), The Judicial Application of Human Rights Law: National, Regional and International Jurisprudence

(Cambridge: Cambridge University Press), p.584. Jayawickrama argues that the right recognized in art 14(7) of ICCPR is broader in scope than the common law principle of autrefois convict. 
Article 56(7) of the African Charter extends the principle of double jeopardy beyond individuals to state parties since it prohibits the African Commission and the African Court from considering a matter that has already been settled. Thus, it establishes the rule ne bis in idem. ${ }^{155}$ Applied to a state, the rule implies that 'a state should not be found in violation twice' for the same action or conduct. ${ }^{156}$

In Bakweri Land Claims Committee v Cameroon, a communication was brought before the African Commission concerning sale of land owned or used by Bakweri, an indigenous community in Cameroon's Fako division. The respondent state raised preliminary objection under Article 56(7) ${ }^{157}$ and argued that the communication was inadmissible as the UN Sub-Commission on the Promotion and Protection of Human Rights had already settled the case. ${ }^{158}$ While explaining the principle behind the requirement under Article 56(7), the Commission held the following: ${ }^{159}$

The principle behind the requirement under this provision of the African Charter is to desist from faulting member states twice for the same alleged violations of human rights. This is called the ne bis in idem rule (also known as the principle or prohibition of double jeopardy, deriving from criminal law) and ensures that, in this context, no state may be sued or condemned for the same alleged violation of human rights.

In Africa, human rights are expected to be protected at four levels: national, subregional, regional and global. ${ }^{160}$ The promotion and protection of human rights at subregional, regional and global levels fall within the international protection of human rights. ${ }^{161}$ Subregional courts are regarded as international courts because they are permanent organs established by international legal instruments and apply international law according to their own rules of procedure on disputes between states or disputes in which one of the parties is a state. ${ }^{162}$ If the cases that are already tried by subregional courts are admissible to the African Commission or the Court, the defendant states would be tried twice for the same conduct before international tribunals. Therefore, admitting cases

\footnotetext{
${ }^{155}$ Viljeon (2007), supra note 1, p. 126.

156 Ibid.

${ }^{157}$ Bakweri Land Claims Committee v Cameroon (2004) AHRLR 43 (ACHPR 2004).

${ }^{158}$ Ibid, para 38.

159 Ibid, para 52.

${ }^{160}$ Viljoen (2007), supra note 1, p. 9. Africa has subregional institutions that deal with human rights.

161 Ibid.

${ }^{162}$ Lucyline Nkata Murungi (2009), 'Revisiting the role of sub-regional courts in the protection of Human rights in Africa' unpublished LLM thesis, University of Pretoria, p. 32.
} 
decided by subregional courts before the African Commission or Court would violate the prohibition of double jeopardy.

\subsection{Res judicata Effect of Subregional Courts' Decisions}

Prohibition of double jeopardy is closely related to the principle of res judicata. The African Commission held that the principle of double jeopardy is connected with 'the recognition of the fundamental res judicata status of judgments issued by international and regional tribunals and/or institutions such as the African Commission." ${ }^{163}$ Res judicata can be defined as: "[a]n affirmative defense barring the same parties from litigating a second lawsuit on the same claim, or any other claim arising from the same transaction or series of transactions and that could have been - but was not - raised in the first suit". ${ }^{164}$

According to the African Commission, res judicata is the principle that a final judgment of a competent court/tribunal is conclusive upon the parties in any subsequent litigation involving the same cause of action. ${ }^{165}$ It implies that 'decision in the circumstances is final, binding and without appeal. ${ }^{166}$

Certain grounds have been advanced to justify res judicata. ${ }^{167}$ First, res judicata serves public interest because the general public interest requires ending 'disputes that have already been litigated by establishing the finality of judicial decisions. ${ }^{168}$ Secondly, it is used as 'a means to reduce controversies and disputes and to promote stability. ${ }^{169}$ Thirdly, it saves courts' time as it ensures 'the economic efficiency of the courts and the speedy termination of controversies. $^{170}$

The ICJ considered the principle of res judicata in Application of the Convention on the Prevention and Punishment of the Crime of Genocide case. ${ }^{171}$

163 Ibid.

${ }^{164}$ Garner, supra note 151, p. 1052.

165 Ibid, para 52.

${ }^{166}$ Malcolm N Shaw (2005), International Law (Cambridge: Cambridge University Press), p. 95.

${ }^{167}$ Yuval Sinai (2011), 'Reconsidering Res Judicata: A Comparative Perspective' Duke Journal of Comparative and International Law 353, Vol. 21, p.360.

168 Ibid.

${ }^{169} \mathrm{Ibid}$, at 362.

${ }^{170}$ Ibid; Edward W. Cleary (1948), 'Res Judicata Reexamined' The Yale Law Journal 339, Vol. 57 No. 3, p. 344.

${ }^{171}$ Case Concerning Application of the Convention on the Prevention and Punishment of the Crime of Genocide (Bosnia and Herzegovina v Serbia and Montenegro)

Judgment of 26 February 2007, International Court of Justice: Reports of Judgments, Advisory Opinions and Orders, available at <http://www.icjcij.org/docket/files/91/13685.pdf> (accessed on 13 February 2013). 
The case dealt with claim of Bosnia and Herzegovina against Serbia and Montenegro for violating the Convention on the Prevention and Punishment of the Crime of Genocide by destroying and attempting to destroy in whole national, ethnical or religious groups within the territory of the Republic of Bosnia and Herzegovina. ${ }^{172}$ The Court identified two purposes of res judicata. ${ }^{173}$ 'First, the stability of legal relations requires that litigation come to an end.' ${ }^{174}$ 'Secondly, it is in the interest of each party that an issue which has already been adjudicated in favour of that party be not argued again. ${ }^{, 175}$

For a case to be barred by res judicata, it must pass 'the triple identity test.' ${ }^{176}$ That is, res judicata 'applies where there is an identity of parties, identity of cause, and identity of subject-matter in between the earlier and subsequent proceedings. ${ }^{177}$ Based on the Civil Procedure Acts of Kenya, Uganda and Tanzania, the East African Court of Justice laid down almost a similar test. ${ }^{178}$ The Court identified three situations that are essential to apply res judicata: ${ }^{179}$ "One, the matter must be 'directly and substantially' in issue in the two suits. Two, parties must be the same or parties under whom any of them claim litigating under the same title. Lastly, the matter was finally decided in the previous suit."

The African Commission applied this test in Bakweri Land Claims Committee case when it held that the "parties before the African Commission have not disputed the fact that they were the very same parties at loggerheads before the UN Sub-Commission disputing the same issues as before the African Commission. ${ }^{180}$ However, the Commission does not consider decision on admissibility as a final settlement of the matter. The principle of res judicata applies when the decision has been taken on the merits.

In this case, the Commission considered a communication that had already been declared inadmissible by the UN Sub-Commission on the Promotion and Protection of Human Rights. ${ }^{181}$ It was of the opinion that had there been final settlement of the matter, the decision of the UN Sub-Commission would have

\footnotetext{
${ }^{172}$ Ibid, para 65.

${ }^{173} \mathrm{Ibid}$, para 116.

174 Ibid.

${ }^{175}$ Ibid.

${ }^{176}$ Michael Ottolenghi \& Peter Prows (2009), 'Res Judicata in the ICJ's Genocide Case: Implications for Other Courts and Tribunals?' Pace International Law Review 37, Vol. 21, at 48.

${ }^{177}$ Genocide case, supra note 162, joint dissenting opinion of judges Ranjeva, Shi and Koroma.

${ }_{178}^{178}$ Katabazi case, supra note 53, para 31.

179 Ibid; see also Garner, supra note 151, p. 1052.

${ }^{180}$ Bakweri Land Claims Committee case, supra note 157, para 53. Emphasis supplied.

${ }^{181} \mathrm{Ibid}$, para 50.
} 
had res judicata status and the case would have been inadmissible under Article 56(7) of the African Charter. ${ }^{182}$ Assuming that its decisions remain consistent, the African Commission is thus expected to recognise the res judicata effect of subregional courts' decisions. The admissibility requirements of the African Commission mutatis mutandis apply to the African Court since both rely on the African Charter.

Analogy can also be made between the African Court and the ICJ. Article 60 of the Statute of the ICJ provides that its judgment is 'final and without appeal.' In Application of the Convention on the Prevention and Punishment of the Crime of Genocide, the ICJ held that the 'fundamental character of that principle appears from the terms of the Statute of the Court and the Charter of the United Nations., ${ }^{183}$

Similarly, the African Court Protocol provides that the "judgment of the Court decided by majority shall be final and not subject to appeal. ${ }^{, 184}$ If the African Court faces cases that have already been decided by subregional courts, it may derive the principle of res judicata from its protocol. The caveat in this analogy is that the ICJ applied the principle in its own previous judgment.

There are exceptions to the principle of res judicata. A court may review and interpret its decisions. For example, the African Court can review its judgment on the basis of new evidence. ${ }^{185}$ It can also interpret its judgment. ${ }^{186}$ With the exception of revision and interpretation, res judicata has the effect of barring the litigants from taking the same case to another court with hopes of obtaining a different judgment, or in anticipation of raising new issues that were not raised at the previous trial. ${ }^{187}$ Therefore, the African Commission and the Court may apply the principle of res judicata to cases that have already decided by subregional courts.

\subsection{Subregional Courts under Article 56(7)}

Article 56(7) of the African Charter deals with the settlement of certain matters without, however, laying down any criterion for identifying an adjudicatory organ. Nevertheless, the African Commission has adopted certain criteria in its jurisprudence. In Constitutional Rights Project $v$ Nigeria, the African Commission held that it is improper to require the complainant to exhaust domestic remedies from a body that does not 'operate impartially' and that has

\footnotetext{
182 Ibid, para 53.

${ }^{183}$ Genocide case, supra note 171 , para 115.

${ }^{184}$ Protocol on the African Court, art 28(2).

185 Ibid, Art 28(3).

${ }^{186}$ Ibid, Art 28(4).

${ }^{187}$ Wild, supra note 153, p. 244.
} 
no 'obligation to decide according to legal principles'. 188 The African Commission "would not rely on the process or mechanism of a 'discretionary, extra-ordinary ... non-judicial nature' to preclude the admissibility of a communication under Article 56(7) of the African Charter". ${ }^{189}$

From the few decisions of the African Commission, it can be gathered that the Commission has depended on the nature of a tribunal or an organ to ascertain whether it falls under Article 56(7) of the African Charter. If a tribunal is of a judicial nature, or if it has an obligation to decide according to legal principles, then it falls under Article 56(7). Interights $v$ Ethiopia and Eritrea illustrates the point. ${ }^{190}$ In this case, the complainant claimed that expulsion or deportation of Eritreans from Ethiopia and that of Ethiopians from Eritrea during the Ethio-Eritrean war of 1998 violated Articles 1, 2, 3, 4, 5, 6, 7(1), 12(1), 12 (2), 12(4), 12(5), 14, 15, 16 and 18(1) of the African Charter. ${ }^{191}$ In their submissions on admissibility, both Eritrea and Ethiopia argued that the communication was inadmissible under Article 56(7) of the African Charter. ${ }^{192}$ The African Commission considered the nature of the Ethiopia-Eritrea Claims Commission that was established by the 2000 Algiers Peace Agreement concluded between Ethiopia and Eritrea. ${ }^{193}$

The African Commission extended the test of 'obligation to decide according to legal principles' to identify organs that fall under Article 56(7) of the African Charter. ${ }^{194}$ The African Commission held that the Ethiopia-Eritrea Claims Commission falls under those bodies envisaged under Article 56(7) as the Claims Commission 'is bound to apply rules of international law and cannot make decisions ex aequo et bono. ${ }^{, 195}$

As the African Commission accepts the Ethiopia-Eritrea Claims Commission as a body envisaged under Article 56(7), it should also view subregional courts in the same way for stronger reasons. Subregional courts are more judicial in nature than the Ethiopia-Eritrea Claims Commission because the former are courts while the latter is an arbitral tribunal. ${ }^{196}$ Consisting of five arbitrators, the

${ }^{188}$ Constitutional Rights Project (in respect of Akamu and Others) v Nigeria (2000) AHRLR 180 (ACHPR 1995), para 8.

${ }^{189}$ Communication 233/99, Interights (on behalf of Pan African Movement and Citizens for Peace in Eritrea) v Ethiopia and Communication 234/99, Interights (on behalf of Pan African Movement and Inter Africa Group) v Eritrea, Sixteenth Activity Report 2002-2003, Annex VII.

${ }^{190}$ Ibid, para 56.

${ }^{191}$ Ibid, para 1-9.

192 Ibid, para 28-29.

193 Algiers Peace Agreement, supra note 148, Art 5.

${ }^{194}$ Interights v. Ethiopia and Eritrea, supra note 189, para 56.

195 Ibid.

${ }^{196}$ See Art 5 of the Algiers Agreement, supra note 148. 
Claims Commission was mandated 'to decide through binding arbitration'197 and the Claims Commission was required to use the 1992 Permanent Court of Arbitration Optional Rules. ${ }^{198}$ Moreover, the Claims Commission is temporary, ${ }^{199}$ while subregional courts are permanent.

The other point stressed by the African Commission is a duty of a court or a tribunal to apply rules of international law to be within the purview of Article 56(7). Obviously, subregional courts have the duty to apply rules of international law. As international treaties constitute one of the primary sources of international law, ${ }^{200}$ subregional courts are empowered to adjudicate on international treaties. ${ }^{201}$ For example, in developing its own jurisprudence, the SADC Tribunal has expressly stated that it should have 'regard to applicable treaties, general principles and rules of public international law and any rules and principles of the law of States. ${ }^{, 202}$ In Campbell the SADC Tribunal referred to several international treaties including the UN Charter while the ECOWAS Court of Justice based its decision on several international human rights treaties. ${ }^{203}$

Subregional courts, albeit few, also have a human rights mandate while the Claims Commission did not have clear human rights mandate. Subregional courts are more likely to deal with human rights cases than the Claims Commission. Moreover, the number of state parties to the treaties establishing subregional courts is greater than that of the parties to the Algiers agreement, if numbers matter at all. Thus, subregional courts are envisaged under Article 56(7) of the African Charter.

\subsection{Textual Interpretation of the African Charter}

The text of the African Charter could be interpreted to include subregional courts. Article 56(7) of the African Charter provides:

Communications relating to human and peoples' rights ... shall be considered if they... [d]o not deal with cases which have been settled by the states involved in accordance with ... [the Constitutive Act of the African Union] or the provisions of the present Charter.

\footnotetext{
${ }^{197}$ Ibid, Art 5(1) \& (2).

198 Ibid, Art 5(7).

199 Ibid, Art 5(8) \& (12).

${ }^{200}$ Art 38(1)(a) of Statute of International Court of Justice.

${ }^{201}$ See Art 27(1) of Treaty Establishing East African Economic Community; Art 16(1) of Consolidated Text of the Treaty of the Southern African Development Community, as Amended.

${ }^{202}$ Art 21(b) of SADC Protocol on the Tribunal and Rules of Procedure Thereof.

${ }^{203}$ Campbell case, supra note 75; Manneh case, supra note 22; Koraou case, supra note 25; SERAP case, supra note 37.
} 
If the case is settled by subregional courts, can such cases be considered as cases that have been settled in accordance with the Constitutive Act of the African Union? Although subregional courts are not organs of the African Union (AU), it could be said that RECs were envisaged within the framework of the AU. For example, Article 3(l) of the Constitutive Act provides that one of the objectives of the AU is to harmonise the activities of RECs. Further evidence that RECs are within the framework of the AU is found in the AU Assembly's Rules of Procedure. ${ }^{204}$ Article 34(2) provides that the regulations and directives of the AU Assembly bind RECs. This provision obviously binds organs of RECs, including subregional courts.

Article 56(7) of the African Charter prohibits the admissibility of cases that have been settled in accordance with the provisions of the African Charter. Subregional courts can settle cases in accordance with the provisions of the African Charter because Article 56(7) of the African Charter does not require that the organ that settles cases in accordance with the African Charter be established by the African Union. Moreover, there is no requirement that such organ should be established on a particular level. Practically speaking, the ECOWAS Community Court of Justice, a subregional court, is deciding cases in accordance with the African Charter. ${ }^{205}$

However, it may be argued that subregional courts were not intended to be included under Article 56(7) because these courts were not established at the time when the African Charter was being drafted. The article only refers to the Organs established by the African Charter or Protocol to the African Charter. In this view, it is only the African Commission or the African Court that can settle cases in accordance with the provisions of the African Charter.

This argument which is based on historical circumstances does not render the 'prudential interpretation ${ }^{206}$ of the African Charter invalid. Giving a monopoly of settling matters in accordance with the African Charter to the continental organs alone requires the insertion of the phrase 'before the organs established by the present Charter' at the end of Article 56(7) of the African Charter. Thus, the text of the African Charter could be understood as precluding the African Commission or the African Court from admitting cases that have already been decided by subregional courts.

${ }^{204}$ Rules of Procedure of the Assembly of the Union, ASS/AU/2(I) - a, Assembly of the African Union, First Ordinary Session 9 - 10 July 2002 Durban, South Africa.

${ }^{205}$ Manneh case, supra note 22; Koraou case, supra note 25; SERAP case, supra note 37.

${ }^{206}$ Here, 'Prudential interpretation' is used to mean the interpretation that allows wise use of the African Court and the African Commission. 


\section{Conclusion}

African Human rights architecture has become substantially different from other regions of the world since subregional courts have ventured into human rights matters. ${ }^{207}$ Human rights mandate of these courts is now clear from their constitutions and decisions although such decisions have had bad consequences for the courts in some instances. However, the relation of subregional courts with the African Commission and the African Court is not clear. In particular, it is not clear whether cases decided by subregional courts are admissible before the African Commission or the African Court.

Cases decided by subregional courts have not yet been submitted to the African Commission or the African Court. The main reason seems to be that the involvement of subregional courts in human rights matters is a recent phenomenon and the number of cases entertained by these courts is very few. As a result, the African Commission or the African Court has not decided on the admissibility of cases from subregional courts. Still, Yogogombaye v Senegal hints that such submission is inevitable and will be made in the near future.

Consideration or revision of subregional courts' decisions by the African Commission or the African Court might have advantages such as ensuring uniform interpretation of the African Charter. However, the legal basis for referring cases from subregional courts to the African Court or the African Commission is shaky. There is not sufficient legal basis for establishing hierarchical structure between the continental human rights bodies and subregional courts.

Admitting cases that have already been decided by subregional courts would have repercussions. It would overburden the African Commission and the African Court as these continental human rights bodies have little time to deal with cases. It would put the defendant state in a difficult position, as the decisions of these courts are final according to treaties establishing them. It would result in trying the defendant states twice by international institutions for the same violation. It would contradict the principles of res judicata. It would contradict some decisions of the African Commission. Therefore, the African Commission and the African Court should not admit cases that have already been decided by subregional courts.

${ }^{207}$ The ECOWAS Community Court of Justice has clear human rights mandate. The SADC Tribunal ruled that it has human rights mandate. The East African Court of Justice upheld human rights despite suspension of its human rights jurisdiction. 